\title{
Pineal gland protects against chemically induced oral carcinogenesis and inhibits tumor progression in rats
}

\author{
Giseli Mitsuy Kayahara'1,2, Vitor Bonetti Valente ${ }^{1}$, Rosani Belzunces Pereira ${ }^{1}$, Felipe \\ Yudi Kabeya Lopes ${ }^{1}$, Marcelo Macedo Crivelini' ${ }^{2}$, Glauco Issamu Miyahara ${ }^{1,2}$, Éder \\ Ricardo Biasoli ${ }^{1,2}$, Sandra Helena Penha Oliveira ${ }^{1,3}$ and Daniel Galera Bernabé ${ }^{1,2}$ \\ ${ }^{1}$ Psychoneuroimmunology Laboratory, Psychosomatic Research Center, Oral Oncology Center, São Paulo State University \\ (Unesp), School of Dentistry, SP 15050-015, Araçatuba, São Paulo, Brazil \\ ${ }^{2}$ Department of Diagnosis and Surgery, São Paulo State University (Unesp), School of Dentistry, SP 15050-015, Araçatuba, \\ São Paulo, Brazil \\ ${ }^{3}$ Laboratory of Immunopharmacology, Department of Basic Sciences, São Paulo State University (Unesp), School of Dentistry, \\ SP 15050-015, Araçatuba, São Paulo, Brazil
}

Correspondence to: Daniel Galera Bernabé, email: daniel.bernabe@unesp.br

Keywords: melatonin; cancer; oral cancer; carcinogenesis; pineal gland

Received: September 10, $2019 \quad$ Accepted: March 14, $2020 \quad$ Published: May 19, 2020

Copyright: Kayahara et al. This is an open-access article distributed under the terms of the Creative Commons Attribution License 3.0 (CC BY 3.0), which permits unrestricted use, distribution, and reproduction in any medium, provided the original author and source are credited.

\section{ABSTRACT}

Clinical investigations suggest that melatonin suppression and circadian dysfunction may be related to cancer development in shift workers. Studies also show that melatonin suppression after pinealectomy increases cancer incidence in preclinical models. However, no study evaluated the influence of pinealectomy on oral cancer development. In the current study, we investigated the effects of pinealectomy on oral squamous cell carcinoma (OSCC) occurrence and progression in rats. Rats submitted to sham surgery were used as control. Pinealectomy promoted an increase of $140 \%$ in OSCC occurrence when compared to sham animals. Tumors from pinealectomized rats displayed a higher volume and thickness than the tumors from sham-operated animals. Pinealectomy induced atrophy of the epithelium adjacent to the oral lesions. Pinealectomized rats showed higher mean number of tumor-associated macrophages and eosinophils in the invasive front of OSCC. In addition, nuclear overexpression of ERK1/2 and p53 was also observed in the front of carcinomas from pinealectomized rats. These results reveal that pineal gland plays a protective role against oral carcinogenesis. The melatonin suppression caused by the pinealectomy might contribute to oral cancer development by acting on ERK1/ 2 and $\mathrm{p} 53$ pathways and regulating tumor inflammation.

\section{INTRODUCTION}

Currently, head and neck cancer (HNC) is the 6th most incident, while only oral cancer affects about 350.000 people worldwide [1]. Studies have shown that melatonin, a major hormone of pineal gland, may be used as adjuvant therapy for cancer treatment [2-4]. In the pineal gland, melatonin (N-acetyl-5-methoxytryptamine) is synthesized in the mitochondria from pinealocytes [5]. In response to darkness, its secretion is controlled by the suprachiasmatic nucleus, which relays photoperiodic information to the pineal via sympathetic nervous system [6]. In addition to the circadian rhythm control, pineal hormone has antioxidant, anti-inflammatory and oncostatic activities [7]. Melatonin may affect tumor growth by reducing cell proliferation and angiogenesis and inhibiting DNA damage [8]. A study showed that lung metastasis of gastric cancer may be inhibited by melatonin through the downregulation of MMP-2, MMP-9, and NF-kB [9]. Moreover, melatonin may increase the activity of tumor suppressor genes and modulate the proliferation and apoptosis of tumor cells through the p53 and ERK $1 / 2$ signaling pathways [8, 10-12]. In Trp53-/- mice, melatonin administration inhibited lymphoma development [13]. Another recent study showed in an orthotopic model of oral cancer that melatonin administration reduced the p-ERK levels in the tumor microenvironment [14]. 
Inflammation plays a critical role in cancer onset and progression [15]. Liu et al. 2019 [16] demonstrated that cancer patients with high systemic inflammation index have lower disease-free survival and reduced distant metastasis-free survival when compared to patients with low inflammation levels. Systemic inflammation has also been associated with an increase in tumor invasion, greater risk of regional metastasis and advanced clinical stage in esophageal cancer patients [17]. Melatonin is considered an important molecule with anti-inflammatory features [18]. In ovarian tumors, the hormone may inhibit the release of proinflammatory cytokines TNF- $\alpha$ and IL6 in the tumor microenvironment [19]. Furthermore, melatonin can promote lower infiltration of eosinophils, IL-17+ inflammatory cells and Foxp3 + cells in the tumor tissue of hamsters with chemically induced cholangiocarcinoma [20].

Melatonin treatment may inhibit cancer progression and metastasis, as well as improve response of HNC patients to chemotherapy [2-4, 21]. Lissoni et al. [4] revealed that HNC patients treated with melatonin and chemotherapy displayed higher 1-year survival rate and increased tumor remission rate than those who received only chemotherapy. In vitro studies show that pineal hormone affects the motility of OSCC cell lines by inhibiting MMP-9 and VEGF transcription, which are molecules known to influence tumor progression [21, 22]. Although melatonin affects cancer progression, its role on the tumorigenesis is poorly known. Moreover, few investigations analyzed the effects of melatonin suppression after pinealectomy on cancer onset in preclinical models. In humans, melatonin suppression can occur in shift workers due to the artificial light exposure during the night periods. Pinealectomy avoids the release of melatonin from pineal gland and can be considered useful to assess the biological effects of pineal hormone suppression in preclinical models of diseases. Studies show that pinealectomized rats display higher incidence of DMBA-induced breast cancer than sham-operated animals [23, 24]. However, no studies have investigated the impact of pinealectomy on other types of cancer. In this research, we used a preclinical oral carcinogenesis model to test the hypothesis that the pinealectomy would promote higher chemically induced oral cancer occurrence and progression in rats.

\section{RESULTS}

\section{Pinealectomy induces higher oral cancer occurrence and progression}

All pinealectomized (PNT) and sham rats were submitted to chemically induced carcinogenesis to investigate the effect of melatonin suppression on oral cancer occurrence. Clinical and histopathological features of OSCC from sham and PNT groups are showed in the
Figure 1A-1F. After carcinogenic induction, PNT rats displayed higher OSCC occurrence than sham animals $(p=0.0029)$ (Figure $1 \mathrm{G})$. According to World Health Organization (WHO) criteria, all PNT rats (100\%) had welldifferentiated OSCC. In the sham group, 54.5\% displayed leukoplakia while only $45.4 \%$ developed well-differentiated OSCC. In addition, pinealectomy also promoted higher tumor growth. PNT rats exhibited higher OSCC volume and thickness than sham rats $(p<0.05)$. The tumor volume was about 3 times higher in PNT rats $\left(73.76 \pm 11.7 \mathrm{~mm}^{3}\right)$ compared to sham animals $\left(27.0 \pm 5.19 \mathrm{~mm}^{3}\right)(p=0.0314)$ (Figure 1H). Furthermore, tumor thickness was twice greater in PNT rats $(1344 \pm 196.1 \mu \mathrm{m})$ than control animals $(600.6 \pm 172.7 \mu \mathrm{m})(p=0.0341)$ (Figure 1I).

\section{Pinealectomy promotes atrophy of non-tumor oral epithelium}

To assess the effects of pinealectomy on the morphologic features of non-tumor epithelium, the thickness of oral epithelium adjacent to the tongue lesions was measured (Figure 2G-2J). After carcinogenic induction, specimens from PNT and sham rats showed no differences regarding the epithelial thickness (PNT: $82.25 \pm 7.628 \mu \mathrm{m}$ vs sham: $98.10 \pm 4.689 \mu \mathrm{m})$, keratin layer thickness (PNT: $49.23 \pm 4.697 \mu \mathrm{m} v s$ sham: $49.22 \pm 3.739 \mu \mathrm{m})$ and total thickness (PNT: $101.3 \pm 12.12 \mu \mathrm{m} v s$ sham: $110.5 \pm 5.195$ $\mu \mathrm{m})$ immediately adjacent to the oral lesion $(p>0.05)$ (Figure $2 \mathrm{~A}-2 \mathrm{C}$ ). Likewise, there was no statistical difference between the groups concerning the non-tumor oral epithelial thickness distant from the lesions (PNT: $45.81 \pm 2.965 \mu \mathrm{m} v s$ sham: $52.70 \pm 3.596 \mu \mathrm{m})(p>0.05)$ (Figure 2D). However, PNT rats displayed lower corneal thickness $(18.19 \pm 1.451 \mu \mathrm{m})$ than sham animals $(25.98 \pm 2.477 \mu \mathrm{m})(p=0.0143)$ (Figure $2 \mathrm{E})$. The total thickness of non-tumor oral epithelium also was reduced in the PNT rats $(64 \pm 4.007 \mu \mathrm{m})$ compared to sham animals $(78.67 \pm 4.725 \mu \mathrm{m})(p=0.0292)$ (Figure $2 \mathrm{~F})$.

\section{Pinealectomy promotes increase of inflammatory cells in the invasive tumor front}

The effects of pinealectomy on inflammatory response were evaluated in the tumor invasion front of the OSCCs from both groups. Student's $t$-test showed that there was no significant difference between the groups concerning the average number of leukocytes (sham: 32.37 \pm 4.104 cells/field $v s$ PNT: $49.20 \pm 6.368$ cells/field) $(p>$ 0.05 ) (Figure $3 \mathrm{~A})$. PNT rats displayed increased average number of eosinophils (PNT: $1.444 \pm 0.2597$ cells/field vs sham: $0.2800 \pm 0.1020$ cells/field) $(p=0.0074)$ (Figure $3 \mathrm{I})$ and macrophages (PNT: $10.53 \pm 0.6379$ cells/field $v s$ sham: $6.924 \pm 0.5910$ cells/field) $(p=0.0014)$ (Figure $3 \mathrm{~K})$ compared to sham animals. However, there were no significant differences between both groups regarding the average number of neutrophils (PNT: $11.74 \pm 2.931$ cells/field $v s$ sham: $3.695 \pm 1.434$ cells/field $)(p>0.05)$ 
(Figure 3C), mast cells (PNT: $7.545 \pm 0.8918$ cells/field vs sham, $8.438 \pm 2.014$ cells/field) $(p>0.05)$ (Figure 3E) and lymphocytes (PNT: $17.45 \pm 1.604$ cells/field $v s$ sham: $14.14 \pm 1.358$ cells/field) $(p>0.05)$ (Figure 3G). In our results, PNT rats displayed tumor volume approximately three times higher than sham group. However, some PNT animals had incipient lesions. Thus, to also examine the association between tumor stage and number of inflammatory cells in the invasive tumor front, carcinomas from PNT rats were classified into early or advanced stages. This classification was made based on a median split of the tumor volume. Advanced tumor-bearing PNT rats displayed higher average number of leukocytes $(p=0.0308)$ (Figure $3 \mathrm{~B})$, lymphocytes $(p=0.0341)$ (Figure $3 \mathrm{H})$ and eosinophils $(p=0.0277)$ (Figure 3J) in the tumor invasion front than sham rats. There were no differences in the average number of neutrophils (Figure 3D) and mast cells (Figure 3F) concerning the tumor stage between PNT and sham rats $(p>0.05)$. Independently of tumor stage, mean number of macrophages was increased in the invasive tumor front from PNT rats $(p=0.0056)$ (Figure $3 \mathrm{~L})$.

\section{PNT rats display higher p53 and ERK1/2 expression in the tumor invasion front}

The expression of tumor progression-related genes, melatonin receptors and carcinogenesis-related proteins were evaluated in the tumor microenvironment from sham and PNT rats. The mRNA levels of VEGF, NFkB, MMP2, MMP9, CDKN2a-p16 and MTNR1a were considerably higher in the carcinomas from PNT rats. However, these results did not reach statistical significance $(p>0.05)$ (Figure 4A-4F). MTNR1b was expressed only in three samples, two from sham group and one from PNT. In the invasive tumor front, there was no difference regarding the PKA immunoexpression between PNT $(28.33 \pm 3.709 \%)$ and sham $(27.80 \pm 3.001 \%)$ rats $(p>0.05)$ (Figure $4 \mathrm{G}, 4 \mathrm{~J}$, $4 \mathrm{~K})$. ERK1/2 immunoexpression was increased in tumor front from PNT animals $(57,05 \pm 4,645 \%)$, compared to sham rats $(43,87 \pm 3,177 \%)(p=0.0451)$ (Figure $4 \mathrm{H}, 4 \mathrm{~L}$, $4 \mathrm{M})$. Similarly, PNT rats exhibited higher p53 expression in the tumor invasion front $(44,35 \pm 4,330 \%)$ than sham rats $(32,99 \pm 1,438 \%)(p=0.0430)$ (Figure 4I, 4N, 4O).
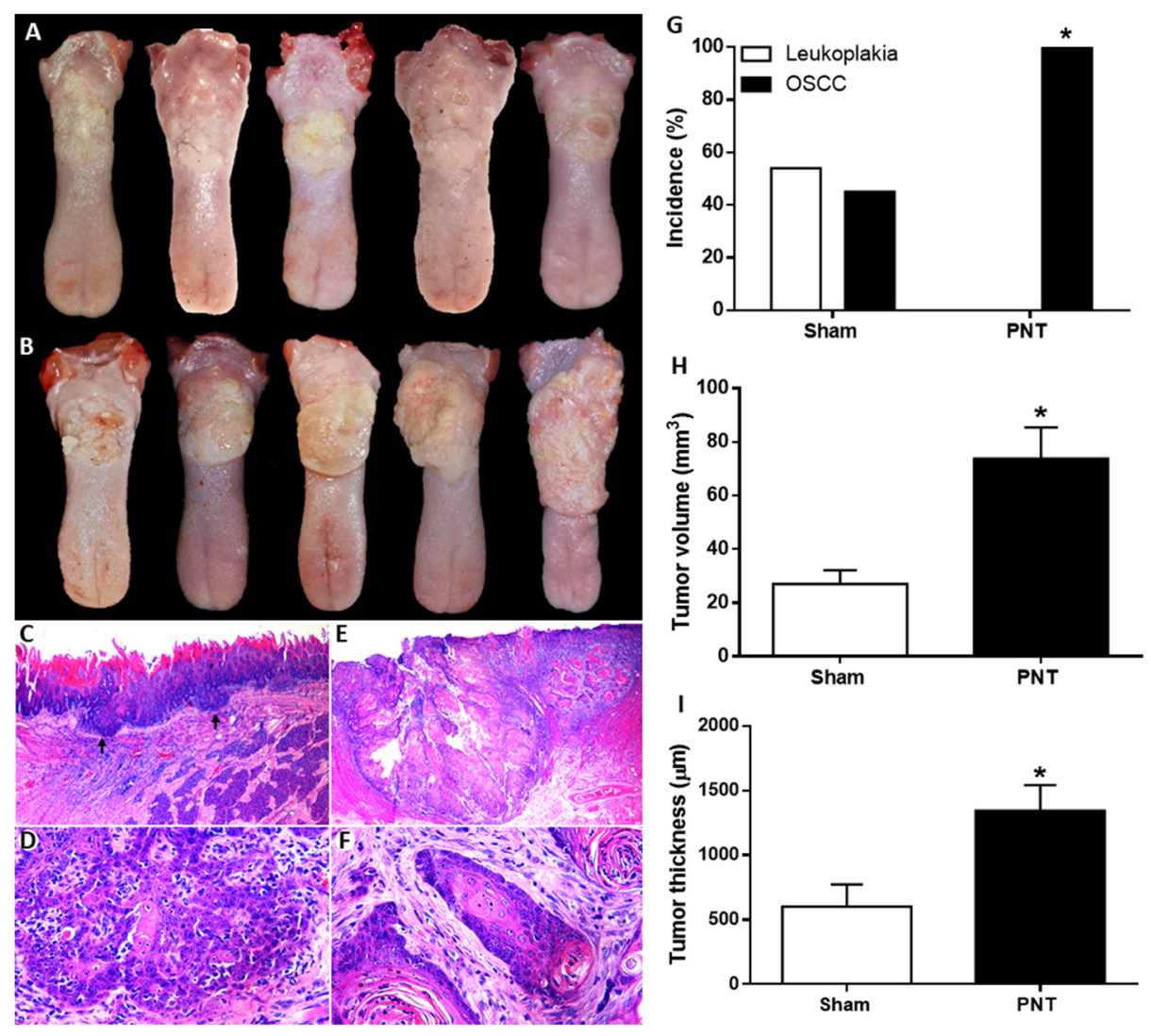

Figure 1: Clinical features of OSCCs derived from 4NQO treatment in sham (A) and PNT rats (B). (A) Small irregular white plates and discrete ulcerative lesions. (B) Extensive ulcerative lesions displaying reddish and yellowish-white areas. Histopathological features of tongue tumors from sham (C and D) and PNT rats (E and F) (H\&E staining). (C) Well-differentiated OSCC (black arrows) (original magnification $\times 250$ ). (D) Tumor cells showing hyperchromatism and dyskeratosis (original magnification $\times 400)$. (E) Extensive welldifferentiated OSCC (original magnification $\times 250$ ). (F) Islands of well-differentiated tumor cells with nuclear pleomorphism and keratin pearls (original magnification $\times 400$ ). Occurrence and progression of OSCC in sham and PNT animals. (G) Chi-square test revealed that PNT rats had a higher OSCC occurrence than sham rats. (H) Student's $t$-test showed that PNT group had increased tumor volume when compared to sham group. (I) PNT rats exhibited higher tumor thickness than sham-operated animals. (sham, $n=11$; PNT, $n=12$ ). Bars represent the mean \pm SEM. ${ }^{*} p<0.05$. The Figure $1 \mathrm{E}$ was spliced for joining together two images due to the extent of the tumor. 


\section{Pinealectomy does not influence the depressive- and anxiety-like behaviors in rats that underwent oral carcinogenesis}

To evaluate the behavioral alterations induced by the pinealectomy, all rats were tested for depressive- and anxiety-like behaviors through Forced Swimming Test (FST) and Elevated Zero Maze (EZM), respectively. Although PNT rats have displayed low-depressive (immobility time in FST, $104.3 \pm 16.01 \mathrm{~s}$ ) and highanxious behavior (time in the open arms in EZM test, $13.9 \pm 4.105 \mathrm{~s})$ compared to sham animals $(164.0 \pm 28.08 \mathrm{~s}$ and $21.0 \pm 3.719 \mathrm{~s}$, respectively), both tests did not reveal statistical differences between the groups $(p>0.05)$ (Figure 5A and 5B). After carcinogenesis, there were also no differences between PNT and sham groups concerning the depressive- (PNT, $134.8 \pm 19.11 \mathrm{~s} v s$ sham,145.0 \pm $11.29 \mathrm{~s})$ and anxiety-like (PNT, $12.08 \pm 5.28 \mathrm{~s} v s$ sham, $17.00 \pm 7.49 \mathrm{~s})$ behavioral phenotype $(p>0.05)$ (Figure $5 \mathrm{~A}$ and $5 \mathrm{~B})$.

\section{DISCUSSION}

In order to evaluate the role of pineal gland and melatonin suppression on oral cancer occurrence and progression in rats, we used a classical pinealectomy model to induce the endogenous melatonin suppression. It is known that pinealectomy abolishes circadian production of pineal hormone and reduces the serum melatonin levels in different animal species [25-31]. Our results
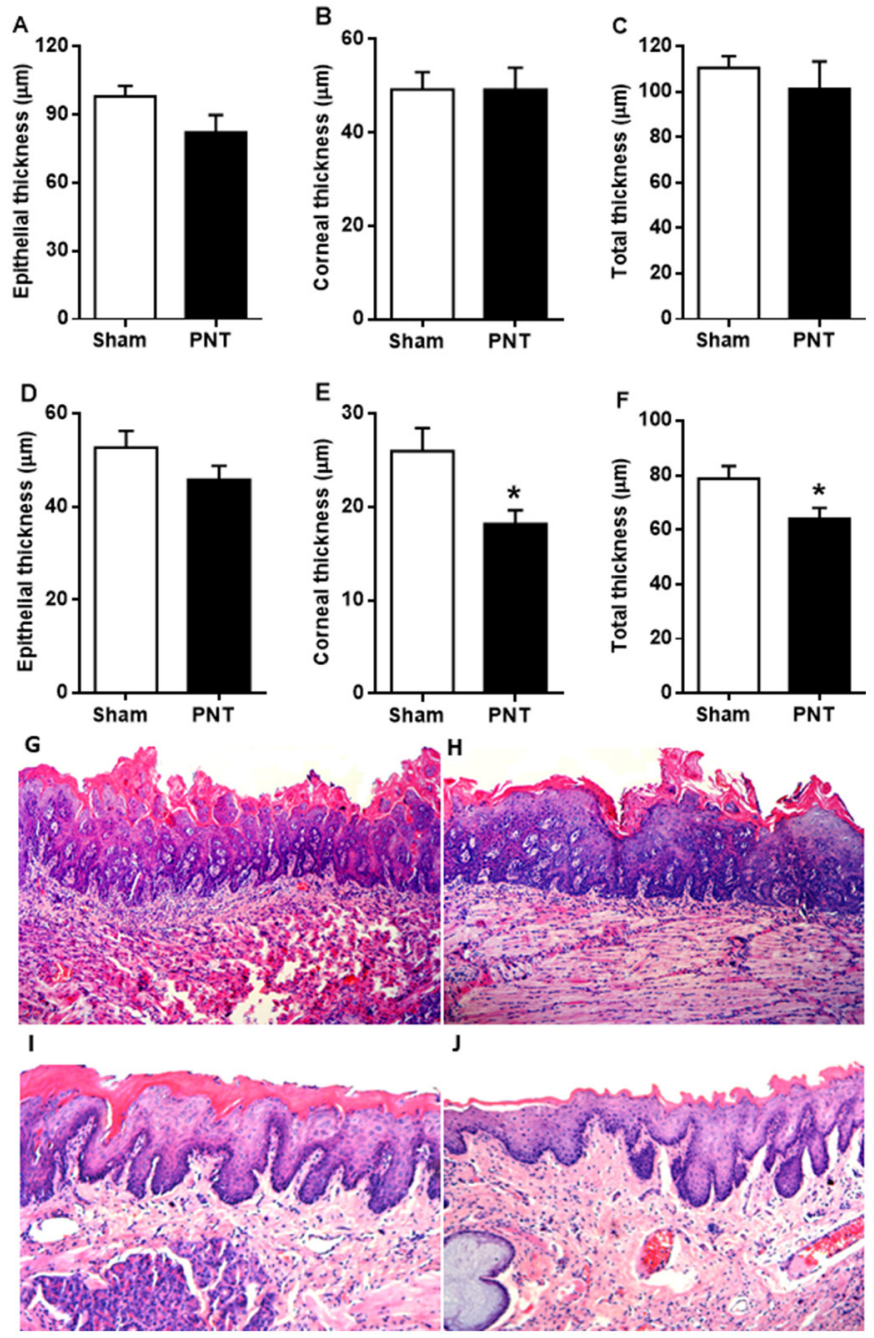

Figure 2: Non-tumor epithelial thickness adjacent to the tongue lesions derived from 4NQO treatment. (A-C) Student's test showed no statistical differences between the groups regarding to epithelial, corneal and total thickness of non-tumor epithelium immediately adjacent to the tongue lesions. Epithelial thickness in distant sites from the lesion. (D) There were no differences between the groups in non-tumor oral epithelial thickness. (E) PNT rats displayed lower corneal thickness of non-tumor epithelium than sham-operated rats. (F) Student's $t$-test revealed that rats from PNT group displayed reduced total thickness of non-tumor epithelium when compared to animals from sham group. ( $\mathbf{G}$ and $\mathbf{H}$ ) Total epithelial thickness immediately adjacent to the lesion from sham and PNT groups, respectively (H\&E, original magnification $\times 100$ ). (I and $\mathbf{J})$ Total epithelial thickness distant from the lesion of sham and PNT animals, respectively $\left(\mathrm{H} \& \mathrm{E}\right.$, original magnification $\times 100$ ). Bars represent the mean \pm SEM. ${ }^{*} p<0.05$ (sham-PNT, $n=10$; PNT, $n=10$ ). The background from histopathological photos were removed. 
provided the first evidences that pinealectomy followed by melatonin suppression may influence oral cancer onset and progression.

In the current study, rats submitted to pinealectomy displayed increased OSCC incidence compared to rats that underwent sham-surgery. Moreover, PNT rats exhibited higher OSCC volume and thickness than sham animals. There are few evidences that show the impact of pinealectomy on cancer progression. Only El-Domeiri \& Das Gupta [32] showed that pinealectomy resulted in higher melanoma growth in hamsters. Otherwise, a growing number of studies have investigated the effects of pineal gland hormone on cancer progression and treatment $[4,33]$. Some studies show that melatonin has oncostatic effects such as the ability to inhibit angiogenesis, cell proliferation and metastatic processes [21, 22]. Melatonin metabolism may also affect cancer growth. Mitochondrial cytochrome P450 1B1 (CP4501B1) metabolizes melatonin to N-acetylserotonin (NAS) into tumor cells, which can induce apoptosis [5]. Furthermore, antitumor mechanisms of melatonin may modulate glucose metabolism [34]. Tumor cells, even in aerobic conditions, convert glucose to lactate (Warburg effect). Warburg effect enables the synthesis of macromolecules that are required for increased cellular proliferation, tumor growth and metastasis [34]. In this context, pineal gland hormone can inhibit the Warburg effect acting as a signal for cancer cells switch from glycolysis to mitochondrial oxidative phosphorylation $[34,35]$. This mechanism has been explored in breast cancer cells and can contribute to reduce tumor progression [34]. Nevertheless, further studies are needed to assess whether the melatonin also inhibits Warburg effect in oral cancer cells.

Several other signaling pathways have also been investigated in relation to melatonin and OSCC. Liu et al. 2018 [14], for example, demonstrated that pineal hormone inhibits the OSCC growth by inactivating ROS-dependet Akt pathway and reducing the expression of cyclin D1, PCNA and Bcl-2. Both mechanisms result in lower cell proliferation and decreased epithelial-mesenchymal transition [14]. Pineal hormone also decreases the expression of pro-angiogenic genes HIF-1 $\alpha$ and VEGF and ROCK-1 pro-metastatic gene [22]. In addition, it promotes transcriptional suppression of the MMP-9 gene, event mediated by reduced histone acetylation [21]. Thus, we suggest that pinealectomy induces opposite effects to the melatonin treatment in tumor cells promoting cell proliferation and increased OSCC progression. Studies have also shown that decreased levels of melatonin may be a risk factor for mammary cancer onset [23, 24, 36]. Nevertheless, to the best of our knowledge, this is the first
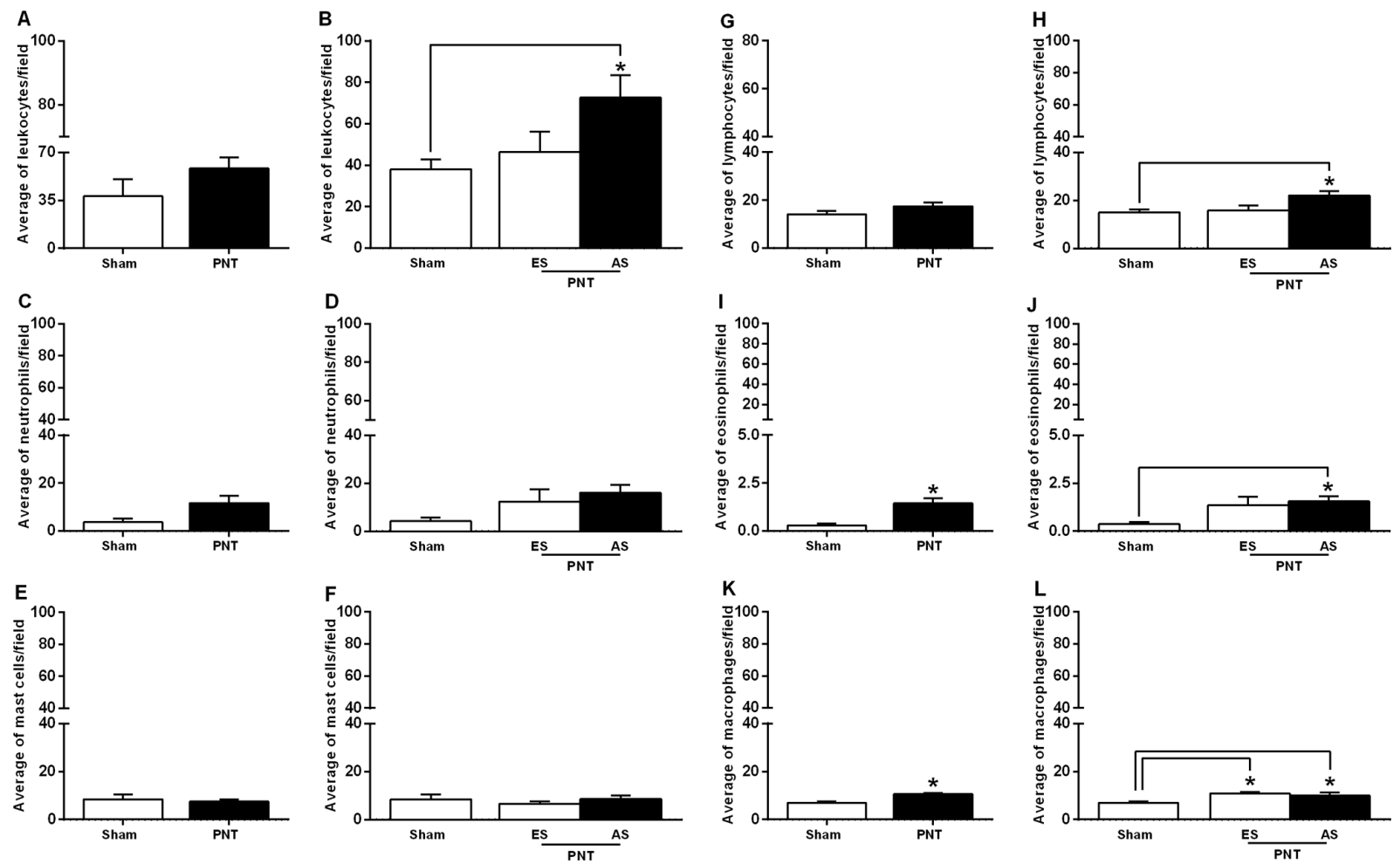

Figure 3: Inflammatory response in the tumor invasion front. Student's $t$-test showed no differences in the average number of leukocytes (A), neutrophils (C), mast cells (E) and lymphocytes $(\mathbf{G})$ in the OSCCs from sham and PNT animals. PNT rats displayed increased average number of tumor-associated eosinophils (I) and macrophages (K) compared to sham animals. In both groups, tumor size was not associated with the average number of neutrophils (D) and mast cells (F) in the tumor invasion front. Advanced tumor-bearing PNT rats had higher average number of leukocytes $(\mathbf{B})$, lymphocytes $(\mathbf{H})$ and eosinophils in the invasive front $(\mathbf{J})$. Early and advanced tumorbearing PNT rats exhibited increased average number of macrophages in the tumor invasion front than sham-operated rats $(\mathbf{L}) .{ }^{*} p<0.05$. Bars represent the mean \pm SEM. ${ }^{*} p<0.05$. ES: Early stage. AS: Advanced stage. (sham, $n=5$; PNT, $n=11$ ). 

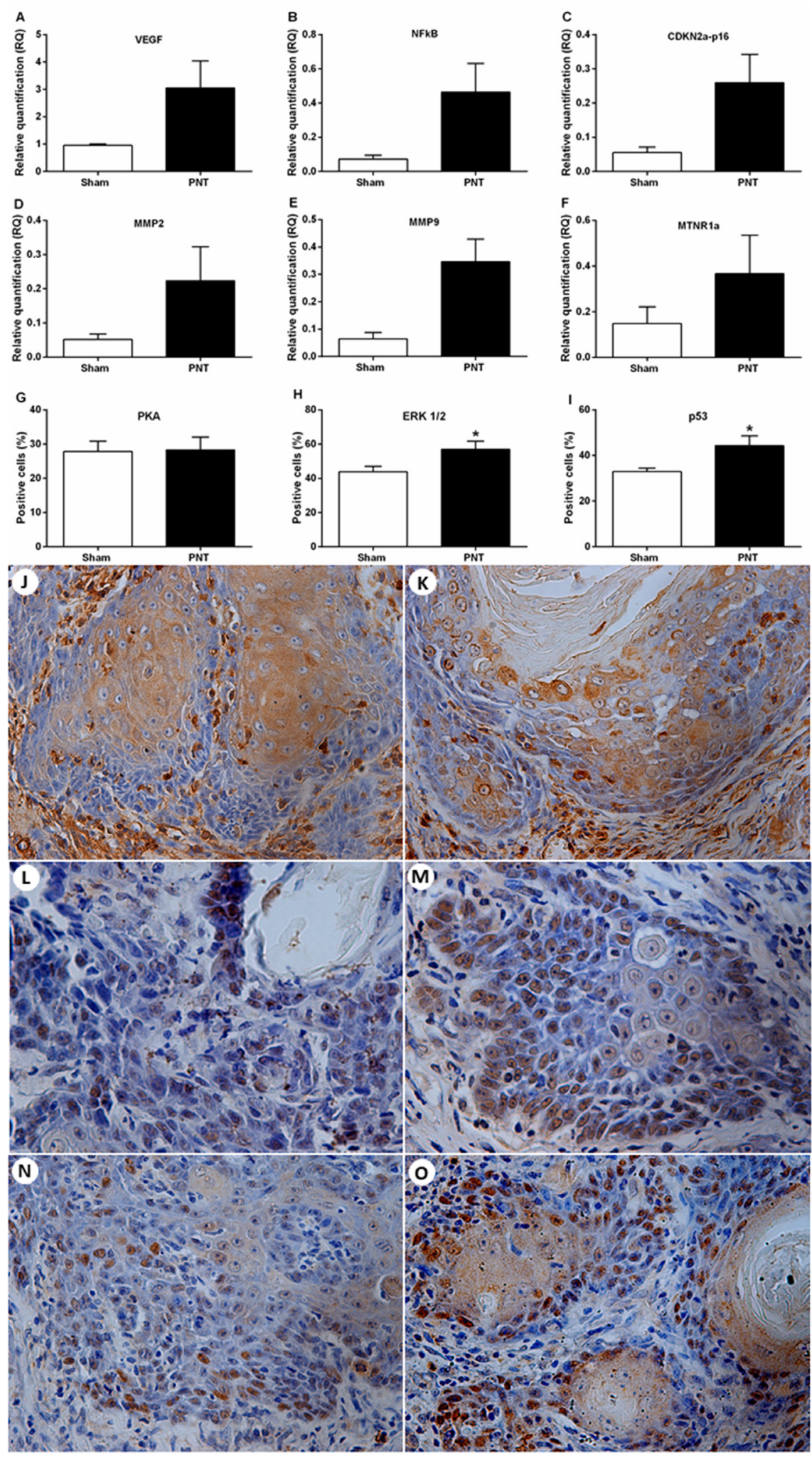

Figure 4: Expression of tumor progression-related genes and melatonin receptors and immunostaining for PKA, ERK1/2 and p53 in the OSCC microenvironment. (A-F) Student's $t$-test showed no differences between the groups concerning the mRNA expression for VEGF, NFkB, CDKN2A-p16, MMP2, MMP9 and MTNR1a in the tumor microenvironment. (G) Student's $t$-test showed no statistical differences between both groups for PKA expression in the OSCCs. (H) PNT rats had increased tumor expression of ERK1/2 compared to sham animals. (I) PNT rats displayed higher tumor expression of nuclear p53 than sham rats. Immunoexpression of PKA ( $\mathbf{J}$ and $\mathbf{K})$, ERK1/2 (L and $\mathbf{M})$ and p53 (N and $\mathbf{O}$ ) in the OSCC invasion front from sham and PNT rats, respectively (original magnification $\times 400$ ). Bars represent the mean \pm SEM. ${ }^{*} p<0.05$. (sham-PNT, $n=7$; PNT, $n=9$ ). 
study that demonstrates the influence of pinealectomy and pineal hormone suppression on oral carcinogenesis.

Pinealectomy can also promote morphometric and biochemical changes in the skin epithelial tissue, such as atrophy of the epithelium and decreased levels of antioxidant enzymes [37]. Here, we hypothesized that the molecular events related to oral carcinogenesis result from pinealectomy and can be accompanied by morphological changes in the oral epithelium. Our results showed that immediately adjacent to the tongue lesions, PNT rats displayed a lower epithelial thickness than sham animals, but this result was not significant. The analysis could have been influenced by the intense cell proliferation that normally occurs near the tumor. In PNT rats, distant regions from the lesion site, exhibited atrophy of corneal layer and total epithelial thickness. Pineal hormone is a powerful free radical scavenger [6]. Unlike, melatonin suppression promotes increase of reactive oxygen species (ROS) concentrations and reduces the levels of antioxidant enzymes in the skin of rats [37]. In non-transformed cells, high levels of ROS tend to promote cell growth arrest and/or cell death [38]. It suggests that the epithelial atrophy displayed by PNT rats may have be caused by a possible increase in the ROS levels into tongue microenvironment, which resulted in a lower proliferation of keratinocytes. The decreased epithelial thickness is associated to higher susceptibility of the mucosa to the penetration of carcinogenic substances [39]. Valentine et al. [40] showed that predisposing factors for oral cancer development such as increased alcohol and tobacco consumption were associated to reduction of the tongue epithelial thickness. Therefore, a lower epithelial thickness in PNT rats would allow a higher infiltration of 4NQO carcinogen through the tongue mucosa leading to increased DNA damage and malignant transformation of the keratinocytes.

Cancer development and progression may be influenced by inflammatory responses [15]. Immune cells can have dual effects on tumorigenesis, eliminating tumor cells or promoting cancer growth [41]. Our results

\section{A}

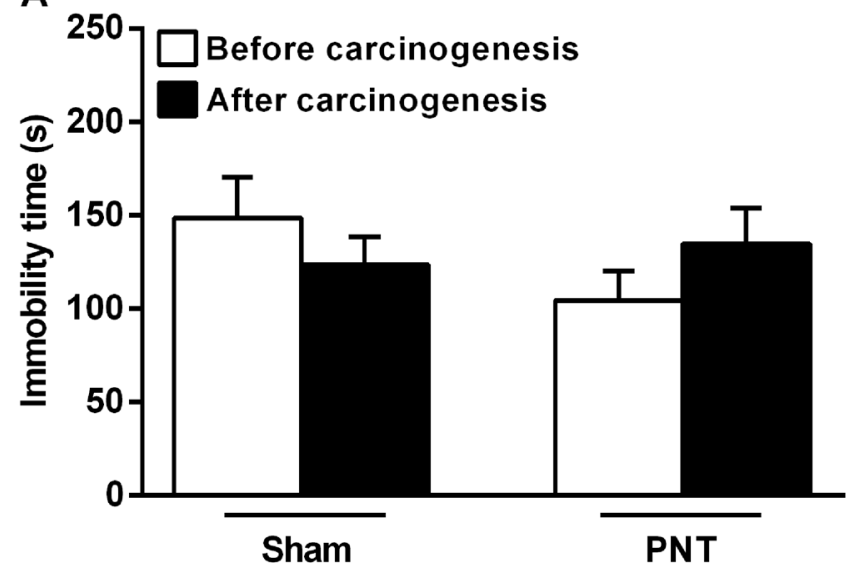

demonstrated that the pineal gland hormone suppression increased the average number of eosinophils and macrophages in the tumor microenvironment. Moreover, large tumors from PNT rats had increased mean number of lymphocytes in the tumor invasion front. Likewise, previous investigations with non-cancer preclinical model showed that pinealectomy promoted an increase in the number of eosinophils and macrophages into peripheral tissues [39, 42]. In a cancer model, melatonin administration suppressed the mean number of eosinophils in cholangiocarcinoma samples [20]. The presence of eosinophils in the breast cancer microenvironment enhances tumor growth and lung metastasis [43]. In human OSCC specimens, tumor-associated macrophages have been positively correlated to tumor size, nodal metastasis, invasive behavior and invasive depth [44, 45]. In addition, tumor-associated eosinophilia has been associated with advanced disease stage and tumor invasion depth $[44,45]$. In PNT rats, our findings strongly suggest that the pineal hormone suppression induced increase of inflammatory cells in the tumor microenvironment contributing to OSCC progression.

Cancer progression may be modulated by melatonin receptor-dependent mechanisms [46]. In the current study, mRNA expression for MTNR1a and MTNR1b genes was detected in the tumor microenvironment. MTNR1a and MTNR1b encode MT1 and MT2 receptors, respectively $[47,48]$. MTNR1a and MTNR1b genes may be expressed in normal tongue microenvironment and OSCC cells [47, 48]. However, in oral cancer cells, melatonin receptors may suffer epigenetic silencing resulting in a lower tissue expression and increased tumor growth [48]. Silencing of MTNR1a gene in OSCC specimens has been correlated to tumor size and shorter overall survival [48]. The expression of MTNR1b in only some specimens of our samples may be associated to genetic alterations that would result in the gene silencing. Investigations have also shown that melatonin may inhibit the expression of

B

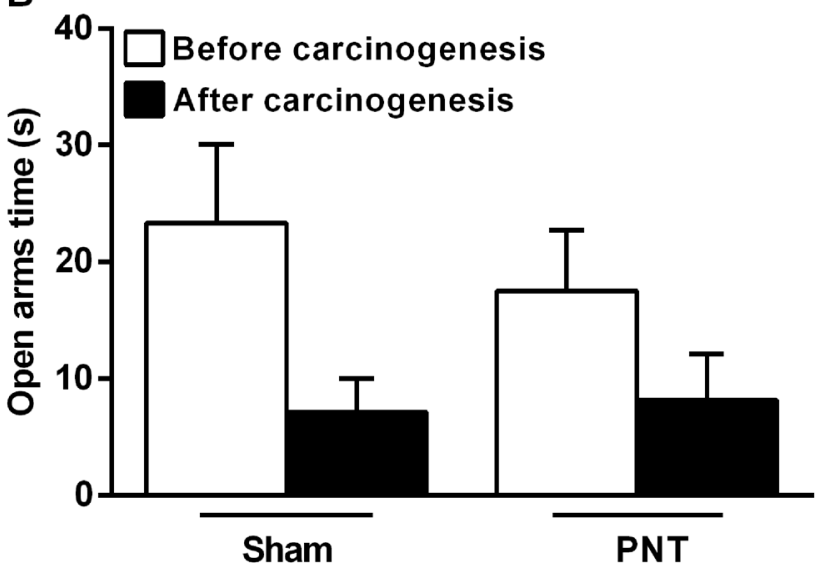

Figure 5: Depressive- and anxiety-like behaviors from sham and PNT rats. (A) There were no differences in the depressivelike behavior from sham and PNT rats pre- and post-carcinogenesis. (B) Student's $t$-test revealed no differences between the groups regarding the anxiety-like behavior before and after carcinogenesis. Bars represent the mean \pm SEM. $p>0.05$. (sham, $n=11$; PNT, $n=12$ ). 
tumor progression-related genes $[49,50]$. A recent study demonstrated that NFkB expression, for example, can be reduced in breast cancer cells treated with melatonin [50]. In ovarian cancer patients, melatonin treatment may control cell invasion and metastasis by decrease in MMP9 activity $[21,22]$. There are still no studies that have evaluated the expression of cancer progression-related genes and proteins in tumors from pinealectomized rats. In our study, mRNA levels for VEGF, NFkB, CDKN2a-p16, MMP2, MMP9 genes were increased in the tumor microenvironment from PNT rats, but the results were not significant because of the high cell heterogeneity found between OSCC samples of both groups. Higher OSCCs displayed a large quantity of tumor cells, whereas lower tumors also exhibited several stromal cells, such as inflammatory cells and fibroblasts, and blood vessels.

Several signaling pathways related to cancer progression may be modulated by melatonin. In our research, pineal hormone suppression did not change the PKA expression in OSCCs. On the other hand, our results showed that PNT rats display increased ERK1/2 expression in the tumor invasion front. Modulation of MAPKs pathways may be involved in anticancer properties of pineal hormone [11]. ERK1/2 belongs to a MAPK pathway and may control several cell responses, such as proliferation, migration, differentiation and death [11]. In non-stimulated conditions, ERK1/2 is anchored to the cell cytoplasm [51]. Nevertheless, mitogens promote activation and nuclear translocation of ERK1/2 for G1 to $\mathrm{S}$ phase progression of the cell cycle [51]. Melatonin modulates differently the ERK $1 / 2$ expression in tumor and non-tumor cells. In non-tumor cells, pineal hormone enhances the ERK1/2 expression and cell viability and inhibits apoptosis [52-54]. On cancer, nuclear ERK1/2 regulates several transcription factors leading to changes in gene expression and increased tumor growth [55]. A growing number of studies have shown that the ERK1/2 protein participates of several oncogenic mechanisms [56]. Pineal hormone acts by inhibiting ERK1/2 expression and the pro-tumorigenic effects of this molecule. On $\mathrm{HNC}$, studies show that melatonin treatment inhibits cell proliferation, migration and invasion [3]. In addition, it may also induce mitochondria-dependent apoptosis and reduce tumor growth [14]. All these anti-tumorigenic effects are controlled by the ERK1/2-mediated signaling pathway suppression [3, 14]. Similar results have also been found in studies with lung $[3,57,58]$, breast [59] cancers, leiomyosarcoma and osteosarcoma [60, 61].

In the current study, besides the increased ERK1/2 expression in tumors from PNT rats, we demonstrated that pinealectomy induced higher expression of nuclear p53 in the OSCC invasive front. Tumor suppressor p53 is an important transcription factor responsible for maintaining genomic stability [62]. In homeostatic conditions, p53 protein is maintained at low levels and the higher concentrations remains in the cell cytoplasm
[63]. Following exposure to stress conditions, p53 protein regulates the activity of various signaling pathways involved with cell growth regulation, cell cycle progression, DNA repair and apoptosis [64]. TP53 gene mutations are the most common genetic alterations in the cancer [65]. These mutations may lead to synthesis and accumulation of dysfunctional proteins in the nucleus of tumor cells allowing the survival of genetically unstable cells [66]. Thus, although there is an increase in p53 expression, its function is impaired by the mutations. p53 nuclear protein overexpression is usually an indicative of the presence of mutant p53 and is commonly seen in OSCCs [67]. There are no studies that have evaluated the tumor p53 expression in tumors from pinealectomized rats. However, melatonin treatment can increase the activity of p53 tumor suppressor signaling pathway, reducing the tumor growth [33]. In the current study, we suggest that melatonin deficiency promoted by the pinealectomy induced an accumulation of dysfunctional p53 proteins in the nucleus of the tumor cells. In short, melatonin may increase the activity of p53 pathways and decrease the ERK1/2 activation. Although the cancer animals were not treated with melatonin, the results of this study suggest that the pinealectomy may promote chemically induced OSCC growth in rats through nuclear overexpression of ERK1/2 and dysfunctional p53.

Pineal hormone suppression may induce biobehavioral alterations in rodents $[68,69]$. However, in our study, we hypothesized that pinealectomized rats would display increased depressive- and anxiety-like behaviors when compared to non-pinealectomized rats. Contrary to our expectations, there were no significant differences between the groups regarding the behavioral phenotype. In shift workers and people who stay up watching TV, using smartphones and/or suffering from insomnia, the artificial light exposure during the night period may inhibit melatonin production [70-72]. Furthermore, chronic tobacco smoking and alcoholism, the main risk factors for oral cancer development, are also associated with decreased systemic melatonin levels [73-75]. In the oral tissues, the melatonin produced by the pineal gland plays an important protective role against mechanisms associated to carcinogenesis, such as mucosa inflammation and oxidative damage $[76,77]$. Melatonin treatment can inhibit the pro-tumorigenic action of lysine-specific demethylase 1 (LSD1), an enzyme that increases OSCC cell proliferation [57]. In oral cancer patients, we suggest that melatonin suppression would be correlated with a higher tumor progression, lower survival rate and worse response to oncological treatment. A clinical trial involving HNC patients showed that melatonin adjuvant treatment suppressed tumor growth and improved survival rate [4].

In humans, prospective studies that allow to evaluate the role of pineal hormone suppression on tumorigenesis require a large population sample with night habits and its long-term follow-up. Pinealectomy 
may be considered a useful method to evaluate the effects of melatonin suppression on cancer onset and progression in preclinical models due to the controlled laboratory conditions. Our research provides evidences about the protective role of pineal gland against chemically induced oral carcinogenesis and tumor progression. In view of our results, harmful habits that result in melatonin suppression could be considered as possible risk factors for HNC occurrence. One limitation of our study is the absence of a pinealectomized group and treated with melatonin in order to evaluate whether the pineal hormone could reverse the pinealectomy effects on cancer onset and progression. Moreover, the systemic melatonin levels were not measured in the groups of pinealectomized and sham-operated rats. The signaling pathways that modulate ERK1/2 and p53 proteins were also not evaluated in this study. Nevertheless, our research provides the first evidences on the role of pineal gland as biological protector against chemically induced oral carcinogenesis and tumor progression (Figure 6). In view of our results, harmful habits that result in decreased melatonin synthesis could be considered as possible risk factors for $\mathrm{HNC}$ occurrence.

\section{MATERIALS AND METHODS}

\section{Animals and experimental design}

In order to assess whether the pinealectomy and melatonin suppression affects oral cancer onset and progression, twenty-three male Wistar rats were housed in groups of 4 animals per cage $(25.9 \times 47.6 \times 20.9 \mathrm{~cm}$, polypropylene) and kept under standardized conditions $\left(22 \pm 2{ }^{\circ} \mathrm{C} ; 12 / 12 \mathrm{~h}\right.$ light/dark cycle; lights on at 7:00 h). The animals were divided into 2 groups: PNT: 12 rats submitted to pinealectomy; Sham: 11 rats submitted to sham surgery. Fifteen days after pinealectomy or sham surgeries, all animals underwent chemically induced oral carcinogenesis for 16 weeks. The rats were also tested for depressive- and anxiety-like behaviors using FST and EZM, respectively. At the end of the experimental period, the animals were euthanized for evaluation of oral cancer occurrence and progression. All the experimental protocols were approved by the Animal Ethics Committee of the São Paulo State University, School of Dentistry, Araçatuba, SP, Brazil (Protocol Number: 00522-2017).

\section{Pinealectomy}

Pinealectomy was performed as described by Hoffman \& Reiter [78]. The rats were anesthetized with intraperitoneal injection of Ketamine Chlorhydrate $10 \%(50 \mathrm{mg} / \mathrm{kg})$ and Xilazine Chlorhydrate $2 \%(5 \mathrm{mg} /$ $\mathrm{kg})$. A sagittal incision was performed on the scalp along the midline. Skin and muscles were pulled away to expose the lambdoid suture. A bone window was created with a circular trephine ( $5 \mathrm{~mm}$ in diameter) on the confluence of the superior sagittal and transverse venous sinuses. Then, the pineal gland was withdrawal and the bonedisk was replaced. The skin and muscles were sutured with surgical suture thread (Shalon $\left.{ }^{\circledR} 4-0\right)$. The animals of sham group were submitted to the same procedures; however, the pineal gland was not removed. Pineal glands from PNT group rats were fixed in $10 \%$ buffered formaldehyde solution (Merck, Darmstadt, Germany) for $48 \mathrm{~h}$. Then, they were dehydrated and paraffin embedded. The histological sections were obtained and stained with hematoxylin and eosin (H\&E). Morphological analysis of tissue was performed by a pathologist to prove that it was in fact the pineal gland.

\section{Behavioral phenotyping}

Behavioral evaluation was accomplished in two phases of the experimental period: 1) two weeks after the surgery (before starting carcinogenic induction) and 2) after carcinogen treatment. Depressive- and anxiety-like behaviors of each experimental group were evaluated by a blinded experienced observer. Forced swimming test: FST was accomplished as described by Porsolt et al. [79]. Firstly, the rats were forced to swim for 15 minutes in a glass cylinder $(13 \mathrm{~cm}$ in diameter $\times 24 \mathrm{~cm}$ in height $)$ filled with water $\left(25^{\circ} \mathrm{C} \pm 2\right)$ (pre-test). On the next day, the rats were forced to swim for 6 minutes at the same pre-test conditions. FST was recorded with a camera positioned 100 centimeters away from the glass cylinder. To evaluate the depressive-like behavior, immobility time of each animal was analyzed. The immobility time was considered as absence of escape-oriented behaviors [30]. Elevated zero maze: EZM is an annular platform elevated $50 \mathrm{~cm}$ above the floor. The apparatus has a diameter of $105 \mathrm{~cm}$ divided into two opposite open arms and two opposite closed arms. The rats were placed individually into one of close arms and their behaviors were recorded for 10 minutes with a camera positioned above of apparatus. The anxiety-like behavior of each animal was analyzed by the time spent in the open arms [80].

\section{Oral carcinogenesis model}

Two weeks after the pinealectomy or sham surgery, all rats were submitted to oral carcinogenesis. For tumor induction, the rats were treated with $50 \mathrm{ppm}$ of 4-nitroquinoline-1-oxide (4NQO) (Sigma-Aldrich, St. Louis, MO, USA) diluted in drinking water [81]. All animals had free access to food (Purina ${ }^{\circledR}$, PaulíniaSP, Brazil) and carcinogen solution, which were replenished twice a week. After 16 weeks of carcinogen treatment, the rats were euthanized and their tongues with carcinogen-induced lesions were removed to perform histopathological and molecular analyzes as well immunohistochemistry reactions. 


\section{Histopathological analysis}

The tongues were longitudinally sectioned and fixed in $10 \%$ buffered formaldehyde solution (Merck, Darmstadt, Germany) for $48 \mathrm{~h}$. The tissues were alcohol dehydrated and paraffin embedded. Histological sections (3 $\mu \mathrm{m}$ of thickness) were obtained and stained with hematoxylin and eosin (H\&E). The tongue lesions were classified in oral leukoplakia or OSCC [82]. OSCC was classified as well-, moderately- or poorly differentiated, according to the WHO classification [83]. Leukoplakia is a precursor lesion of OSCC. The following microscopic features were considered for the diagnosis of oral leukoplakia: epithelial atrophy, acanthosis with or without hyperkeratosis and epithelial dysplasia [84]. The degree of epithelial dysplasia was classified into mild, moderate or severe [83]. Microscopic examination was performed by an experienced oral pathologist who was blinded to the experimental groups.

\section{Tumor thickness and volume}

The three-dimensional measurements of the tumor were obtained with a digital caliper. The tumor volume was calculated in $\mathrm{mm}^{3}$ using the formula: depth $\times$ width $\times$ length [82]. To evaluate the tumor thickness, OSCC slides were photographed on a microscope equipped with a digital camera (Zeiss Axio imager Z1 microscope, Carl Zeiss, Munchen-Hallbergmoos, Germany). The measurements were obtained in $\mu \mathrm{m}$ from the deepest point of tumor invasion to the surface of the lesion using the ImageJ software [82].

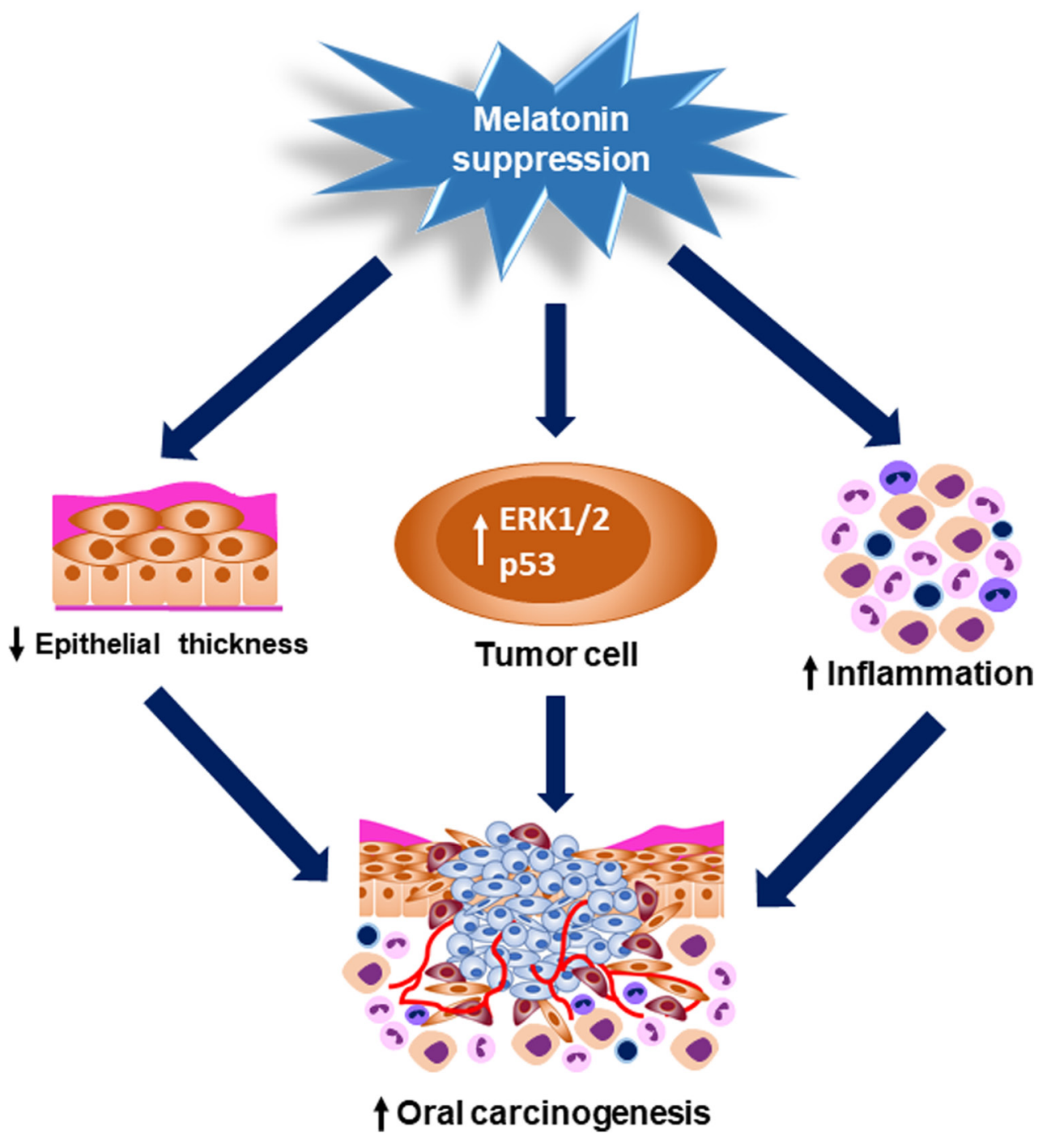

Figure 6: Graphical abstract showing the pinealectomy effects on OSCC occurrence and progression. Pinealectomy induced a significant reduction of the oral epithelium thickness, which may have increased the mucosa susceptibility to the chemical carcinogen. Moreover, melatonin suppression up-regulated the nuclear levels of ERK1/2 and p53 in the tumor cells and also increased the number of inflammatory cells in the tumor invasive front. All of these mechanisms could contribute to the oral carcinogenesis and tumor progression. 


\section{Non-tumor epithelial thickness}

The non-tumor epithelium thickness adjacent to the tongue lesions was obtained in $\mu \mathrm{m}$ by the distance between basal cell layer and granular layer. Corneal thickness was assessed by the measure between the lucid layer and corneal layer surface. Total epithelial thickness was measured between the basal cell layer and apical epithelial surface (epithelium + corneal layer) [85]. All measurements were performed by a blinded researcher to the experimental groups. On each slide, 4 fields were analyzed: two fields immediately adjacent to the tongue lesions and two distant fields from the lesion site. For statistical analysis, the mean thickness of epithelium and corneal layer were calculated between two fields immediately adjacent to the tongue lesions and between two distant fields from the lesion.

\section{Inflammatory cells quantification in the tumor invasion front}

To evaluate the influence of melatonin suppression on tumor inflammatory response in sham and PNT rats, the average number of neutrophils, eosinophils, macrophages, lymphocytes and mast cells were quantified in OSCC slides stained with H\&E, at $1000 \times$ magnification (Leica DM2500, Leica Biosystems, Wetzlar, Germany). On each slide, five fields of tumor invasion front were assessed. The analysis was performed by a blind researcher to experimental groups.

\section{Immunohistochemistry}

Histological sections of OSCC were deparaffinized and rehydrated to immunohistochemistry evaluation. Heat-induced epitope retrieval was performed by $10 \mathrm{mM}$ citrate buffer, $\mathrm{pH} 6.0$, at $55^{\circ} \mathrm{C}$ for 20 minutes. Blockade of endogenous peroxidase activity was accomplished by $3 \% \mathrm{H}_{2} \mathrm{O}_{2}$ for 20 minutes. The slides were washed with PBS solution ( $\mathrm{pH}$ 7.2). Sections were then incubed with primary antibody anti-p53 (dilution 1:100; Santa Cruz Biotechnology, Santa Cruz, CA, USA), anti-PKA (dilution 1:3000; Santa Cruz Biotechnology, Santa Cruz, CA, USA) and anti-ERK1/2 (dilution 1:200; Santa Cruz Biotechnology, Santa Cruz, CA, USA) at $4^{\circ} \mathrm{C}$ overnight. The sections were incubated with Histofine antibody polymer conjugated with horseradish peroxidase (Nichirei Biosciences, Tokyo, Japan) for 30 minutes. The slides were washed with PBS buffer and a chromogenic substrate $\left(3,3^{\prime}, 5,5^{\prime}\right.$-tetramethylbenzidine) was incubated for 5 minutes. Reactions were stopped in deionized water. Counter-staining was performed by Harris's hematoxylin for 20 seconds. The histological sections were dehydrated and covered with coverslip for microscopic examination. In the tumor invasive front, a total of 1000 tumor cells was assessed in 2-4 fields at $400 \times$ magnification. The percentage of immunopositive cells was used to express the results. All the analyzes were performed by a blinded examiner to the experimental conditions.

\section{Expression of tumor progression-related genes and melatonin receptors}

Real time-PCR technique was performed to assess the mRNA expression levels for VEGF, NFkB, MMP-2, MMP-9 and CDKN2a-p16 in the tumor microenvironment. These genes were chosen because they are associated to oral cancer development and progression. VEGF promotes tumor angiogenesis [86]. MMP-2 and -9 are known to influence degradation of the extracellular matrix and contribute to tumor invasion and metastasis [87, 88]. CDKN2a-p16 is an important tumor-suppressor gene often associated to oral cancer development [89]. NFkB is a proinflammatory transcription factor that plays a pivotal role in tumorigenesis and oral cancer progression [90]. The mRNA expression levels for MTNR1a and MTNR2a melatonin receptors were also examined in the tumors from both experimental groups. The tumor specimens were washed in saline solution, immersed in TRIzol (Invitrogen Life Technologies, USA) and stored at $-80^{\circ} \mathrm{C}$. Total RNA was extracted for synthesis of complementary DNA (cDNA). RNA quantity and quality were evaluated by Nanodrop 2000 (Thermo Scientific, Wilmington, USA). cDNA was synthesized using the High Capacity RNA to cDNA kit (Invitrogen Life Technologies). TaqMan $^{\text {TM }}$ RT-PCR assay measured the mRNA expression levels by the StepOne Real-Time PCR system (Applied Biosystems, Foster City, CA, USA). The primers used were VEGF (Rn01511601_m1), NFkB (Rn01310378 g1), MMP-2 (Rn01538170_m1), MMP-9 (Rn00579162_ m1), CDKN2a-p16 (Rn00580664_m1), MTNR1a (Rn01488022_m1) and MTNR1b (Rn01447987_m1). $\beta$-actin (Rn00562253_m1) gene was used as endogenous control. mRNA Relative Quantity (RQ) for each target gene was calculated using the comparative $\mathrm{Ct}$ method. The assays were performed in duplicate.

\section{Statistical analysis}

GraphPad Prism 6.01 software (GraphPad Software Inc., San Diego, CA, USA) was used to perform the statistical analysis. Chi-square test was performed to assess the OSCC incidence in both experimental groups. Student's $t$-test was used to determine the differences between PNT and sham-operated rats regarding the tumor volume and thickness, epithelial thickness, number of inflammatory cells, mRNA and protein levels and behavioral measures. Analysis of variance (Oneway ANOVA) with post-test Tukey-Kramer multiple comparison analysis was performed to determine the differences between the mean of inflammatory cells in the tumor invasion front of sham animals and early- or 
advanced tumor-bearing PNT rats. The level of statistical significance was set at a $p$ value less than $0.05(p<0.05)$ for all statistical tests.

\section{CONCLUSIONS}

Taken together, our results reveal for the first time that pinealectomy followed by melatonin suppression may induce higher oral cancer occurrence and progression in a preclinical model. Our findings suggest that chemically induced OSCC development can be influenced by decreased epithelial thickness after pinealectomy. Furthermore, the accelerated tumor progression in pinealectomized rats could be mediated by increase of tumor-associated macrophages and eosinophils and ERK1/2 oncogenic protein, besides p53 inactivation.

\section{Abbreviations}

OSCC: Oral squamous cell carcinoma; ERK1/2: Extracellular signal-regulated kinases; HNC: Head and Neck Carcinoma; MMP-2: Matrix Metalloproteinase-2; MMP-9: Matrix Metalloproteinase-2; NF-kB: Factor Nuclear kappa B; VEGF: Vascular endothelial growth fator; DMBA: 7,12-Dimethylbenz(a)anthracene; PNT: Pinealectomized; WHO: World Health Organization; FST: Forced swimming test; EZM: Elevated Zero Maze; CP4501B1: Cytochrome P 4501B1; NAS: $\mathrm{N}$-acetylserotonin; acetyl-CoA: Acetyl coenzyme A; ROS: Reactive oxygen species; PCNA: Proliferating cell nuclear antigen; HIF-1 $\alpha$ : Hypoxia inducible factor- $1 \alpha$; 4NQO: 4-Nitroquinoline 1-oxide; mRNA: Messenger RNA; MT1: Melatonin receptor 1; MT2: Melatonina receptor 2; PKA: Protein Kinase A; MAPK: Mitogen-activated protein kinase; DNA: Deoxyribonucleic acid; LSD1: lysine-specific demethylase 1; ppm: Parts per million; $\mu \mathrm{m}$ : Micrometer; H\&E: Hematoxylin and Eosin; $\mathrm{mm}^{3}$ : Cubic Millimeters; $\mathrm{H}_{2} \mathrm{O}_{2}$ : Hydrogen Peroxide; PBS: Phosphate buffer Solution; PCR: Polymerase Chain Reaction; RNA: Ribonucleic acid; cDNA: Complementary DNA; RT-PCR: Real Time Polymerase Chain Reaction.

\section{Author contributions}

Conceptualization: Daniel Galera Bernabé, Data curation: Giseli Mitsuy Kayahara, Vitor Bonetti Valente, Rosani Belzunces Pereira, Felipe Yudi Kabeya Lopes, Marcelo Macedo Crivelini, Glauco Issamu Miyahara, Éder Ricardo Biasoli, Sandra Helena Penha Oliveira, Daniel Galera Bernabé, Formal analysis: Vitor Bonetti Valente, Marcelo Macedo Crivelini, Glauco Issamu Miyahara, Éder Ricardo Biasoli, Sandra Helena Penha Oliveira, Daniel Galera Bernabé, Funding acquisition: Daniel Galera Bernabé, Sandra Helena Penha Oliveira, Investigation: Giseli Mitsuy Kayahara, Éder Ricardo Biasoli, Glauco Issamu Miyahara, Methodology: Giseli
Mitsuy Kayahara, Vitor Bonetti Valente, Felipe Yudi Kabeya Lopes, Rosani Belzunces Pereira, Daniel Galera Bernabé, Project administration: Daniel Galera Bernabé, Resources: Daniel Galera Bernabé, Visualization: Glauco Issamu Miyahara, Writing the original draft: Giseli Mitsuy Kayahara, Writing - Review and editing: Vitor Bonetti Valente, Éder Ricardo Biasoli, Daniel Galera Bernabé.

\section{CONFLICTS OF INTEREST}

None.

\section{FUNDING}

This research was supported by the São Paulo Research Foundation (FAPESP, grant number. 2016/25255-0).

\section{REFERENCES}

1. Bray F, Ferlay J, Soerjomataram I, Siegel RL, Torre LA, Jemal A. Global cancer statistics 2018: GLOBOCAN estimates of incidence and mortality worldwide for 36 cancers in 185 countries. CA Cancer J Clin. 2018; 6:394424. https://doi.org/10.3322/caac.21492. [PubMed]

2. Li Y, Li S, Zhou Y, Meng X, Zhang JJ, Xu DP, Li HB. Melatonin for the prevention and treatment of cancer. Oncotarget. 2017; 8:39896-39921. https://doi.org/10.18632/ oncotarget.16379. [PubMed]

3. Lu YX, Chen DL, Wang DS, Chen LZ, Mo HY, Sheng H, Bai L, Wu QN, Yu HE, Xie D, Yun JP, Zeng ZL, Wang $\mathrm{F}$, et al. Melatonin enhances sensitivity to fluorouracil in oesophageal squamous cell carcinoma through inhibition of Erk and Akt pathway. Cell Death Dis. 2016; 10:e2432. https://doi.org/10.1038/cddis.2016.330. [PubMed]

4. Lissoni $\mathrm{P}$, Barni $\mathrm{S}$, Mandalà $\mathrm{M}$, Ardizzoia $\mathrm{A}$, Paolorossi $\mathrm{F}$, Vaghi M, Longarini R, Malugani F, Tancini G. Decreased toxicity and increased efficacy of cancer chemotherapy using the pineal hormone melatonin in metastatic solid tumour patients with poor clinical status. Eur J Cancer. 1999; 12:1688-92. https://doi.org/10.1016/S0959-8049(99)00159-8. [PubMed]

5. Tan DX, Reiter RJ. Mitochondria: the birth place, battle ground and the site of melatonin metabolism in cells. Melatonin Research. 2019; 2:44-66. https://doi. org/10.32794/mr11250011.

6. Tan DX, Manchester LC, Esteban-Zubero E, Zhou Z, Reiter RJ. Melatonin as a Potent and Inducible Endogenous Antioxidant: Synthesis and Metabolism. Molecules. 2015; 10:18886-906. https://doi.org/10.3390/ molecules201018886. [PubMed]

7. Karaaslan C, Suzen S. Antioxidant properties of melatonin and its potential action in diseases. Curr Top Med Chem. 2015; 9:894-903. https://doi.org/10.2174/1568026615666 150220120946. [PubMed] 
8. Panzer A, Viljoen M. The validity of melatonin as an oncostatic agent. J Pineal Res. 1997; 4:184-202. https:// doi.org/10.1111/j.1600-079x.1997.tb00322.x. [PubMed]

9. Wang X, Wang B, Zhan W, Kang L, Zhang S, Chen C, Hou D, You R, Huang H. Melatonin inhibits lung metastasis of gastric cancer in vivo. Biomed Pharmacother. 2019; 117:109018. https://doi.org/10.1016/j.biopha.2019.109018. [PubMed]

10. Santoro R, Mori F, Marani M, Grasso G, Cambria MA, Blandino G, Muti P, Strano S. Blockage of melatonin receptors impairs p53-mediated prevention of DNA damage accumulation. Carcinogenesis. 2013; 34:1051-1061. https:// doi.org/10.1093/carcin/bgt025. [PubMed]

11. Cagnol S, Chambard JC. ERK and cell death: mechanisms of ERK-induced cell death-apoptosis, autophagy and senescence. FEBS J. 2010; 1:2-21. https://doi.org/10.1111/ j.1742-4658.2009.07366.x. [PubMed]

12. Olea-Flores M, Zuñiga-Eulogio MD, Mendoza-Catalán MA, Rodríguez-Ruiz HA, Castañeda-Saucedo E, Ortuño-Pineda C, Padilla-Benavides T, Navarro-Tito N. Extracellular-Signal Regulated Kinase: A Central Molecule Driving EpithelialMesenchymal Transition in Cancer. Int J Mol Sci. 2019; 20:2885. https://doi.org/10.3390/ijms20122885. [PubMed]

13. Huang HS, Chu SC, Hsu CF, Chen PC, Ding DC, Chang MY, Chu TY. Mutagenic, surviving and tumorigenic effects of follicular fluid in the context of p53 loss: initiation of fimbria carcinogenesis. Carcinogenesis. 2015; 11:1419-28. https://doi.org/10.1093/carcin/bgv132. [PubMed]

14. Liu R, Wang HL, Deng MJ, Wen XJ, Mo YY, Chen FM, Zou CL, Duan WF, Li L, Nie X. Melatonin Inhibits Reactive Oxygen Species-Driven Proliferation, EpithelialMesenchymal Transition, and Vasculogenic Mimicry in Oral Cancer. Oxid Med Cell Longev. 2018; 2018:3510970. https://doi.org/10.1155/2018/3510970. [PubMed]

15. Coussens LM, Werb Z. Inflammation and cancer. Nature. 2002; 6917:860-7. https://doi.org/10.1038/nature01322. [PubMed]

16. Liu J, Shi Z, Bai Y, Liu L, Cheng K. Prognostic significance of systemic immune-inflammation index in triple-negative breast cancer. Cancer Manag Res. 2019; 11:4471-4480. https://doi.org/10.2147/CMAR.S197623. [PubMed]

17. Zhang Y, Xiao G, Wang R. Clinical significance of systemic immune-inflammation index (SII) and C-reactive proteinto-albumin ratio (CAR) in patients with esophageal cancer: a meta-analysis. Cancer Manag Res. 2019; 11:4185-4200. https://doi.org/10.2147/CMAR.S190006. [PubMed]

18. Najafi M, Shirazi A, Motevaseli E, Rezaeyan AH, Salajegheh A, Rezapoor S. Melatonin as an anti-inflammatory agent in radiotherapy. Inflammopharmacology. 2017; 25:403-13. https://doi.org/10.1007/s10787-017-0332-5. [PubMed]

19. Chuffa LG, Fioruci-Fontanelli BA, Mendes LO, Ferreira Seiva FR, Martinez M, Fávaro WJ, Domeniconi RF, Pinheiro PF, Delazari Dos Santos L, Martinez FE. Melatonin attenuates the TLR4-mediated inflammatory response through MyD88- and TRIF-dependent signaling pathways in an in vivo model of ovarian cancer. BMC Cancer. 2015; 15:34. https://doi.org/10.1186/s12885-0151032-4. [PubMed]

20. Wongsena W, Charoensuk L, Dangtakot R, Pinlaor P, Intuyod K, Pinlaor S. Melatonin suppresses eosinophils and Th17 cells in hamsters treated with a combination of human liver fluke infection and a chemical carcinogen. Pharmacol Rep. 2018; 1:98-105. https://doi.org/10.1016/j. pharep.2017.07.017. [PubMed]

21. Yeh CM, Lin CW, Yang JS, Yang WE, Su SC, Yang SF. Melatonin inhibits TPA-induced oral cancer cell migration by suppressing matrix metalloproteinase-9 activation through the histone acetylation. Oncotarget. 2016; 7:2195221967. https://doi.org/10.18632/oncotarget.8009. [PubMed]

22. Goncalves Ndo N, Rodrigues RV, Jardim-Perassi BV, Moschetta MG, Lopes JR, Colombo J, Zuccari DA. Molecular markers of angiogenesis and metastasis in lines of oral carcinoma after treatment with melatonin. Anticancer Agents Med Chem. 2014; 9:1302-11. https:// doi.org/10.2174/1871520614666140812110246. [PubMed]

23. Tamarkin L, Cohen M, Roselle D, Reichert C, Lippman M, Chabner B. Melatonin inhibition and pinealectomy enhancement of 7,12-dimethylbenz(a)anthracene-induced mammary tumors in the rat. Cancer Res. 1981; 41:4432-6. [PubMed]

24. Shah PN, Mhatre MC, Kothari LS. Effect of melatonin on mammary carcinogenesis in intact and pinealectomized rats in varying photoperiods. Cancer Res. 1984; 44:3403-7. [PubMed]

25. Lewy AJ, Tetsuo M, Markey SP, Goodwin FK, Kopin IJ. Pinealectomy abolishes plasma melatonin in the rat. J Clin Endocrinol Metab. 1980; 50:204-5. https://doi.org/10.1210/ jcem-50-1-204. [PubMed]

26. Janik D, Dittami J, Gwinner E. The effect of pinealectomy on circadian plasma melatonin levels in house sparrows and European starlings. J Biol Rhythms. 1992; 7:277-86. https://doi.org/10.1177/074873049200700402. [PubMed]

27. Foà $\mathrm{A}$, Janik D, Minutini L. Circadian rhythms of plasma melatonin in the ruin lizard Podarcis sicula: effects of pinealectomy. J Pineal Res. 1992; 12:109-13. https://doi. org/10.1111/j.1600-079x.1992.tb00036.x. [PubMed]

28. Bubenik GA, Brown GM. Pinealectomy reduces melatonin levels in the serum but not in the gastrointestinal tract of rats. Biol Signals. 1997; 6:40-4. https://doi. org/10.1159/000109107. [PubMed]

29. Wang Y, Liu X, Wang W, Song W, Chen L, Fang Q, Yan $\mathrm{X}$. The expression of inflammatory cytokines on the aorta endothelia are up-regulated in pinealectomized rats. Inflammation. 2013; 36:1363-73. https://doi.org/10.1007/ s10753-013-9676-1. [PubMed]

30. Bian J, Wang Z, Dong Y, Cao J, Chen Y. Effect of pinealectomy on the circadian clock of the chick retina under different monochromatic lights. Chronobiol Int. 2019; 36:548-563. https://doi.org/10.1080/07420528.2019.15667 40. [PubMed] 
31. Chen L, Zhou T, Wu N, O'Brien A, Venter J, Ceci L, Kyritsi K, Onori P, Gaudio E, Sybenga A, Xie L, Wu C, Fabris L, et al. Pinealectomy or light exposure exacerbates biliary damage and liver fibrosis in cholestatic rats through decreased melatonin synthesis. Biochim Biophys Acta Mol Basis Dis. 2019; 1865:1525-1539. https://doi.org/10.1016/j. bbadis.2019.03.002. [PubMed]

32. El-Domeiri AA, Das Gupta TK. The influence of pineal ablation and administration of melatonin on growth and spread of hamster melanoma. J Surg Oncol. 1976; 3:197205. https://doi.org/10.1002/jso.2930080303. [PubMed]

33. Amin AH, El-Missiry MA, Othman AI, Ali DA, Gouida MS, Ismail AH. Ameliorative effects of melatonin against solid Ehrlich carcinoma progression in female mice. J Pineal Res. 2019; 8:e12585. https://doi.org/10.1111/ jpi.12585. [PubMed]

34. Reiter RJ, Sharma R, Ma Q, Rosales-Corral S, AcunaCastroviejo D, Escames G. Inhibition of mitochondrial pyruvate dehydrogenase kinase: a proposed mechanism by which melatonin causes cancer cells to overcome cytosolic glycolysis, reduce tumor biomass and reverse insensitivity to chemotherapy. Melatonin Research. 2019; 2:105-119. https://oi.org/10.32794/mr11250033.

35. Blask DE, Dauchy RT, Dauchy EM, Mao L, Hill SM, Greene MW, Belancio VP, Sauer LA, Davidson L. Light exposure at night disrupts host/cancer circadian regulatory dynamics: impact on the Warburg effect, lipid signaling and tumor growth prevention. PLoS One. 2014; 9:e102776. https://doi.org/10.1371/journal.pone.0102776. [PubMed]

36. Devore EE, Warner ET, Eliassen AH, Brown SB, Beck AH, Hankinson SE, Schernhammer ES. Urinary Melatonin in Relation to Postmenopausal Breast Cancer Risk According to Melatonin 1 Receptor Status. Cancer Epidemiol Biomarkers Prev. 2017; 3:413-419. https://doi. org/10.1158/1055-9965.EPI-16-0630. [PubMed]

37. Eşrefoglu M, Seyhan M, Gül M, Parlakpinar H, Batçioğlu K, Uyumlu B. Potent therapeutic effect of melatonin on aging skin in pinealectomized rats. J Pineal Res. 2005; 3:231-7. https://doi.org/10.1111/j.1600-079X.2005.00235.x. [PubMed]

38. Martindale JL, Holbrook NJ. Cellular response to oxidative stress: signaling for suicide and survival. J Cell Physiol. 2002; 192:1-15. https://doi.org/10.1002/jcp.10119. [PubMed]

39. Wight AJ, Ogden GR. Possible mechanisms by which alcohol may influence the development of oral cancer-a review. Oral Oncol. 1998; 6:441-7. https://doi.org/10.1016/ S1368-8375(98)00022-0. [PubMed]

40. Valentine JA, Scott J, West CR, St Hill CA. A histological analysis of the early effects of alcohol and tobacco usage on human lingual epithelium. J Oral Pathol. 1985; 14:654-65. https://doi.org/10.1111/j.1600-0714.1985.tb00543.x. [PubMed]

41. Gajewski TF, Schreiber H, Fu YX. Innate and adaptive immune cells in the tumor microenvironment. Nat Immunol. 2013; 10:1014-22. https://doi.org/10.1038/ ni.2703. [PubMed]
42. Dair EL, Simoes RS, Simões MJ, Romeu LR, OliveiraFilho RM, Haidar MA, Baracat EC, Soares JM Jr. Effects of melatonin on the endometrial morphology and embryo implantation in rats. Fertil Steril. 2008 (Suppl 5); 89:1299-305. https://doi.org/10.1016/i.fertnstert.2007.03.050. [PubMed]

43. Panagopoulos V, Leach DA, Zinonos I, Ponomarev V, Licari G, Liapis V, Ingman WV, Anderson P, DeNichilo MO, Evdokiou A. Inflammatory peroxidases promote breast cancer progression in mice via regulation of the tumour microenvironment. Int J Oncol. 2017; 4:1191-1200. https:// doi.org/10.3892/ijo.2017.3883. [PubMed]

44. Kouketsu A, Sato I, Oikawa M, Shimizu Y, Saito H, Tashiro K, Yamashita Y, Takahashi T, Kumamoto H. Regulatory T cells and M2-polarized tumour-associated macrophages are associated with the oncogenesis and progression of oral squamous cell carcinoma. Int J Oral Maxillofac Surg. 2019; 19:31084-7. https://doi.org/10.1016/j.ijom.2019.04.004. [PubMed]

45. De Paz D, Chang KP, Kao HK, Lao WW, Huang YC, Chang YL, Huang Y. Clinical Implications of Tumor-Associated Tissue Eosinophilia in Tongue Squamous Cell Carcinoma. Laryngoscope. 2019; 5:1123-1129. https://doi.org/10.1002/ lary.27413. [PubMed]

46. Jockers R, Delagrange P, Dubocovich ML, Markus RP, Renault N, Tosini G, Cecon E, Zlotos DP. Update on melatonin receptors: IUPHAR Review 20. Br J Pharmacol. 2016; 173:2702-25. https://doi.org/10.1111/bph.13536. [PubMed]

47. Ortiz F, Acuña-Castroviejo D, Doerrier C, Dayoub JC, López LC, Venegas C, García JA, López A, Volt H, Luna-Sánchez M, Escames G. Melatonin blunts the mitochondrial/NLRP3 connection and protects against radiation-induced oral mucositis. J Pineal Res. 2015; 58:3449. https://doi.org/10.1111/jpi.12191. [PubMed]

48. Nakamura E, Kozaki K, Tsuda H, Suzuki E, Pimkhaokham A, Yamamoto G, Irie T, Tachikawa T, Amagasa T, Inazawa $\mathrm{J}$, Imoto I. Frequent silencing of a putative tumor suppressor gene melatonin receptor $1 \mathrm{~A}(\mathrm{MTNR} 1 \mathrm{~A})$ in oral squamouscell carcinoma. Cancer Sci. 2008; 99:1390-400. https://doi. org/10.1111/j.1349-7006.2008.00838.x. [PubMed]

49. Wang X, Wang B, Xie J, Hou D, Zhang H, Huang H. Melatonin inhibits epithelial-to-mesenchymal transition in gastric cancer cells via attenuation of IL-1 $\beta / \mathrm{NF}-\kappa \mathrm{B} / \mathrm{MMP} 2 /$ MMP9 signaling. Int J Mol Med. 2018; 4:2221-2228. https://doi.org/10.3892/ijmm.2018.3788. [PubMed]

50. Colombo J, Jardim-Perassi BV, Ferreira JPS, Braga CZ, Sonehara NM, Júnior RP, Moschetta MG, Girol AP, Zuccari DAPC. Melatonin Differentially Modulates NF-кB Expression in Breast and Liver Cancer Cells. Anticancer Agents Med Chem. 2018; 12:1688-1694. https://doi.org/10 $.2174 / 1871520618666180131112304$. [PubMed]

51. Mebratu Y, Tesfaigzi Y. How ERK1/2 activation controls cell proliferation and cell death: Is subcellular localization the answer? Cell Cycle. 2009; 8:1168-75. https://doi. org/10.4161/cc.8.8.8147. [PubMed] 
52. Li P, Hu F, Cao X, Luo L, Tu Q. Melatonin receptor protects cardiomyocyte against oxidative stress-induced apoptosis through the MAPK-ERK signaling pathway. J Recept Signal Transduct Res. 2020; 40:117-125. https://doi.org/1 $\underline{0.1080 / 10799893.2020 .1719151 .}$. [PubMed]

53. Ge J, Zhou Q, Niu J, Wang Y, Yan Q, Wu C, Qian J, Yang $\mathrm{H}$, Zou J. Melatonin Protects Intervertebral Disc from Degeneration by Improving Cell Survival and Function via Activation of the ERK1/2 Signaling pathway. Oxid Med Cell Longev. 2019; 2019:5120275. https://doi. org/10.1155/2019/5120275. [ [PubMed]

54. Beker MC, Caglayan B, Caglayan AB, Kelestemur T, Yalcin E, Caglayan A, Kilic U, Baykal AT, Reiter RJ, Kilic E. Interaction of melatonin and Bmal1 in the regulation of PI3K/AKT pathway components and cellular survival. Sci Rep. 2019; 9:19082. https://doi.org/10.1038/s41598-01955663-0. [PubMed]

55. Roberts PJ, Der CJ. Targeting the Raf-MEK-ERK mitogenactivated protein kinase cascade for the treatment of cancer. Oncogene. 2007; 26:3291-310. https://doi.org/10.1038/ sj.onc.1210422. [PubMed]

56. Ratner N, Miller SJ. A RASopathy gene commonly mutated in cancer: the neurofibromatosis type 1 tumour suppressor. Nat Rev Cancer. 2015; 15:290-301. https://doi.org/10.1038/ nrc3911. [PubMed]

57. Yang CY, Lin CK, Tsao CH, Hsieh CC, Lin GJ, Ma KH, Shieh YS, Sytwu HK, Chen YW. Melatonin exerts antioral cancer effect via suppressing LSD1 in patient-derived tumor xenograft models. Oncotarget. 2017; 8:33756-33769. https://doi.org/10.18632/oncotarget.16808. [PubMed]

58. Chao CC, Chen PC, Chiou PC, Hsu CJ, Liu PI, Yang YC, Reiter RJ, Yang SF, Tang CH. Melatonin suppresses lung cancer metastasis by inhibition of epithelial-mesenchymal transition through targeting to Twist. Clin Sci (Lond). 2019; 133:709-722. https://doi.org/10.1042/CS20180945. [PubMed]

59. Proietti S, Catizone A, Masiello MG, Dinicola S, Fabrizi G, Minini M, Ricci G, Verna R, Reiter RJ, Cucina A, Bizzarri $\mathrm{M}$. Increase in motility and invasiveness of MCF7 cancer cells induced by nicotine is abolished by melatonin through inhibition of ERK phosphorylation. J Pineal Res. 2018; 64:e12467. https://doi.org/10.1111/jpi.12467. [ubMed]

60. Lu KH, Su SC, Lin CW, Hsieh YH, Lin YC, Chien MH, Reiter RJ, Yang SF. Melatonin attenuates osteosarcoma cell invasion by suppression of C-C motif chemokine ligand 24 through inhibition of the c-Jun N-terminal kinase pathway. J Pineal Res. 2018; 65:e12507. https://doi.org/10.1111/jpi.12507. [PubMed]

61. Dauchy RT, Blask DE, Dauchy EM, Davidson LK, Tirrell PC, Greene MW, Tirrell RP, Hill CR, Sauer LA. Antineoplastic effects of melatonin on a rare malignancy of mesenchymal origin: melatonin receptor-mediated inhibition of signal transduction, linoleic acid metabolism and growth in issue-isolated human leiomyosarcoma xenografts. J Pineal Res. 2009; 47:32-42. https://doi. org/10.1111/j.1600-079X.2009.00686.x. [ [PubMed]
62. Vogelstein B, Lane D, Levine AJ. Surfing the p53 network. Nature. 2000; 408:307-10. https://doi. org/10.1038/35042675. [PubMed]

63. Green DR, Kroemer G. Cytoplasmic functions of the tumour suppressor p53. Nature. 2009; 458:1127-30. https:// doi.org/10.1038/nature07986. [PubMed]

64. Hanahan D, Weinberg RA. Hallmarks of cancer: the next generation. Cell. 2011; 144:646-74. https://doi. org/10.1016/j.cell.2011.02.013. [PubMed]

65. Wu GS. The functional interactions between the p53 and MAPK signaling pathways. Cancer Biol Ther. 2004; 3:15661. https://doi.org/10.4161/cbt.3.2.614. [PubMed]

66. Soussi T. p53 Antibodies in the sera of patients with various types of cancer: a review. Cancer Res. 2000; 60:1777-88. [PubMed]

67. Shahnavaz SA, Regezi JA, Bradley G, Dubé ID, Jordan RC. p53 gene mutations in sequential oral epithelial dysplasias and squamous cell carcinomas. J Pathol. 2000; 190:417-22. https:// doi.org/10.1002/(SICI)1096-9896(200003)190:4<417::AID$\underline{\text { PATH544>3.0.CO;2-G. [PubMed] }}$

68. Bustamante-García R, Lira-Rocha AS, Espejo-González O, Gómez-Martínez AE, Picazo O. Anxiolytic-like effects of a new 1-N substituted analog of melatonin in pinealectomized rats. Prog Neuropsychopharmacol Biol Psychiatry. 2014; 51:133-9. https://doi.org/10.1016/j.pnpbp.2014.01.015. [PubMed]

69. Tchekalarova J, Nenchovska Z, Atanasova D, Atanasova M, Kortenska L, Stefanova M, Alova L, Lazarov N. Consequences of long-term treatment with agomelatine on depressive-like behavior and neurobiological abnormalities in pinealectomized rats. Behav Brain Res. 2016; 302:11-28. https://doi.org/10.1016/j.bbr.2015.12.043. [PubMed]

70. Hunter CM, Figueiro MG. Measuring Light at Night and Melatonin Levels in Shift Workers: A Review of the Literature. Biol Res Nurs. 2017; 4:365-374. https://doi. org/10.1177/1099800417714069. [PubMed]

71. Touitou Y, Reinberg A, Touitou D. Association between light at night, melatonin secretion, sleep deprivation, and the internal clock: Health impacts and mechanisms of circadian disruption. Life Sci. 2017; 173:94-106. https:// doi.org/10.1016/j.lfs.2017.02.008. [PubMed]

72. Razavi P, Devore EE, Bajaj A, Lockley SW, Figueiro MG, Ricchiuti V, Gauderman WJ, Hankinson SE, Willett WC, Schernhammer E. Shift Work, Chronotype, and Melatonin Rhythm in Nurses. Cancer Epidemiol Biomarkers Prev. 2019; 28:1177-1186. https://doi.org/10.1158/1055-9965. EPI-18-1018. [PubMed]

73. Ozguner F, Koyu A, Cesur G. Active smoking causes oxidative stress and decreases blood melatonin levels. Toxicol Ind Health. 2005; 21:21-6. https://doi.org/10.1191/0748233705th211oa. [PubMed]

74. Schernhammer ES, Kroenke CH, Dowsett M, Folkerd E, Hankinson SE. Urinary 6-sulfatoxymelatonin levels and their correlations with lifestyle factors and steroid 
hormone levels. J Pineal Res. 2006; 40:116-24. https://doi. org/10.1111/j.1600-079X.2005.00285.x. [PubMed]

75. Conroy DA, Hairston IS, Arnedt JT, Hoffmann RF, Armitage R, Brower KJ. Dim light melatonin onset in alcohol-dependent men and women compared with healthy controls. Chronobiol Int. 2012; 29:35-42. https://doi.org/1 0.3109/07420528.2011.636852. [PubMed]

76. Santos RMD, Marani F, Chiba FY, Mattera MSLC, Tsosura TVS, Tessarin GWL, Pereira RF, Belardi BE, Pinheiro BCES, Sumida DH. Melatonin promotes reduction in TNF levels and improves the lipid profile and insulin sensitivity in pinealectomized rats with periodontal disease. Life Sci. 2018; 213:32-39. https://doi.org/10.1016/j.lfs.2018.09.056. [PubMed]

77. Reiter RJ, Tan D, Kim SJ, Manchester LC, Qi W, Garcia JJ, Cabrera JC, El-Sokkary G, Rouvier-Garay V. Augmentation of indices of oxidative damage in life-long melatonindeficient rats. Mech Ageing Dev. 1999; 110:157-73. https:// doi.org/10.1016/S0047-6374(99)00058-5. [PubMed]

78. Hoffman RA, Reiter RJ. Rapid pinealectomy in hamsters and other small rodents. Anat Rec. 1965; 1:19-21. https:// doi.org/10.1002/ar.1091530103. [PubMed]

79. Porsolt RD, Bertin A, Jalfre M. Behavioral despair in mice: a primary screening test for antidepressants. Arch Int Pharmacodyn Ther. 1977; 229:327-36. [PubMed]

80. Shepherd JK, Grewal SS, Fletcher A, Bill DJ, Dourish CT. Behavioural and pharmacological characterization of the elevated "zero-maze" as an animal model of anxiety. Psychopharmacology (Berl). 1994; 1:56-64. https://doi. org/10.1007/bf02244871. [PubMed]

81. Kanojia D, Vaidya MM. 4-nitroquinoline-1-oxide induced experimental oral carcinogenesis. Oral Oncol. 2006; 7:655667. https://doi.org/10.1016/j.oraloncology.2005.10.013. [PubMed]

82. Valente VB, Verza FA, Lopes FYK, Ferreira JZ, Dos Santos PSP, Sundefeld MLMM, Biasoli ÉR, Miyahara GI, Soubhia AMP, de Andrade M, de Oliveira SHP, Bernabé DG. Stress hormones concentrations in the normal microenvironment predict risk for chemically induced cancer in rats. Psychoneuroendocrinology. 2018; 89:229-238. https://doi. org/10.1016/j.psyneuen.2017.11.001. [PubMed]

83. El-Naggar AK, Chan JKC, Grandis JR, Takata T, Slootweg PJ. WHO classification of head and neck tumours, 9th ed. Lyon: IARC; 2017.
84. van der Waal I, Schepman KP, van der Meij EH, Smeele LE. Oral leukoplakia: a clinicopathological review. Oral Oncol. 1997; 5:291-301. https://doi.org/10.1016/S13688375(97)00002-X. [ [PubMed]

85. Alvisi S, Baldassarre M, Gava G, Mancini I, Gagliardi M, Seracchioli R, Meriggiola MC. Structure of Epithelial and Stromal Compartments of Vulvar and Vaginal Tissue From Women With Vulvo-Vaginal Atrophy Taking Ospemifene. J Sex Med. 2018; 15:1776-1784. https://doi.org/10.1016/j. jsxm.2018.10.009. [PubMed]

86. Patel KR, Vajaria BN, Begum R, Patel JB, Shah FD, Joshi GM, Patel PS. VEGFA isoforms play a vital role in oral cancer progression. Tumour Biol. 2015; 36:6321-32. https://doi.org/10.1007/s13277-015-3318-1. [PubMed]

87. Lu L, Xue X, Lan J, Gao Y, Xiong Z, Zhang H, Jiang W, Song W, Zhi Q. MicroRNA-29a upregulates MMP2 in oral squamous cell carcinoma to promote cancer invasion and anti-apoptosis. Biomed Pharmacother. 2014; 68:13-9. https://doi.org/10.1016/j.biopha.2013.10.005. [PubMed]

88. Hsu LS, Huang RH, Lai HW, Hsu HT, Sung WW, Hsieh $\mathrm{MJ}, \mathrm{Wu} \mathrm{CY}$, Lin YM, Chen MK, Lo YS, Chen CJ. KLF6 inhibited oral cancer migration and invasion via downregulation of mesenchymal markers and inhibition of MMP-9 activities. Int J Med Sci. 2017; 14:530-535. https:// doi.org/10.7150/ijms.19024. [PubMed]

89. Lim AM, Do H, Young RJ, Wong SQ, Angel C, Collins M, Takano EA, Corry J, Wiesenfeld D, Kleid S, Sigston E, Lyons B, Fox SB, et al. Differential mechanisms of CDKN2A (p16) alteration in oral tongue squamous cell carcinomas and correlation with patient outcome. Int J Cancer. 2014; 135:887-95. https://doi.org/10.1002/ ijc.28727. [PubMed]

90. Mishra A, Bharti AC, Varghese P, Saluja D, Das BC. Differential expression and activation of NF-kappaB family proteins during oral carcinogenesis: Role of high risk human papillomavirus infection. Int J Cancer. 2006; 119:2840-50. https://doi.org/10.1002/ijc.22262. [PubMed] 